\title{
Research Progress and Perspectives of Nitrogen Fixing Bacterium, Gluconacetobacter diazotrophicus, in Monocot Plants
}

\author{
N. Eskin, ${ }^{1,2}$ K. Vessey, ${ }^{3}$ and L. Tian ${ }^{2}$ \\ ${ }^{1}$ Department of Biology, University of Western Ontario, 1151 Richmond Street, London, ON, Canada N6A 3K7 \\ ${ }^{2}$ Southern Crop Protection and Food Research Centre, Agriculture and Agri-Food Canada, 1391 Sandford Street, \\ London, ON, Canada N5V 4T3 \\ ${ }^{3}$ Department of Biology, Saint Mary's University, 923 Robie Street, Halifax, NS, Canada B3H 3C3
}

Correspondence should be addressed to L. Tian; lining.tian@agr.gc.ca

Received 12 November 2013; Accepted 14 December 2013; Published 7 May 2014

Academic Editor: Iskender Tiryaki

Copyright (C) 2014 N. Eskin et al. This is an open access article distributed under the Creative Commons Attribution License, which permits unrestricted use, distribution, and reproduction in any medium, provided the original work is properly cited.

Gluconacetobacter diazotrophicus is a nitrogen fixing bacterium originally found in monocotyledon sugarcane plants in which the bacterium actively fixes atmosphere nitrogen and provides significant amounts of nitrogen to plants. This bacterium mainly colonizes intercellular spaces within the roots and stems of plants and does not require the formation of the complex root organ like nodule. The bacterium is less plant/crop specific and indeed G. diazotrophicus has been found in a number of unrelated plant species. Importantly, as the bacterium was of monocot plant origin, there exists a possibility that the nitrogen fixation feature of the bacterium may be used in many other monocot crops. This paper reviews and updates the research progress of G. diazotrophicus for the past 25 years but focuses on the recent research development.

\section{Introduction}

Nitrogen is a primary constituent of nucleotides, proteins, and chlorophyll in plants. Although the atmosphere is $78 \%$ nitrogen, its diatomic form makes it inaccessible to plants due to the presence of a triple bond [1]. Modern plant agriculture heavily relies on industry nitrogen fertilizers to maintain optimum yields [2]. However, nitrogen fertilizers are expensive, quadrupling in price from 1999 to 2008 [3]. The production and use of nitrogen fertilizers also contribute significantly to greenhouse gas emissions [4]. Additionally, many farmers apply supraoptimal amounts of fertilizers to their fields as a means of risk management and insurance against possible nitrogen losses to ensure maximum attainable yields $[3,5,6]$. Adding to this, the fact that nitrogen is mobile, reactive, and hard to contain makes it very vulnerable to losses due to denitrification, volatilization, and leaching [7-9]. Leached reactive forms of nitrogen are capable of causing widespread environmental effects and severe consequences to human health $[3,10-12]$. Due to increased costs and detrimental effects on the environment associated with nitrogen fertilizers and negative field and yield effects resulting from continuous monoculture practices, farmers rely on crop rotation to both provide benefits to the agricultural system and add fixednitrogen into the soil through the process of biological nitrogen fixation (BNF) [2].

Biological nitrogen fixation can be defined as the reduction of dinitrogen to ammonia by means of a prokaryote [13]. However, not all plants have acquired a symbiosis with a nitrogen fixing prokaryote [14], primarily due to the fact that a large amount of prokaryotes capable of BNF, such as rhizobia, has a very selective host range [15]. One of the principal reasons for host selection by rhizobia is due to nodule formation, which requires a series of reciprocal molecular conversation signals between the bacterium and host plant which leads to changes in the transcriptional regulation of genes, structural changes, and eventually the formation of a root nodule, the epicentre of BNF in legumes [16]. However, not all prokaryotes capable of BNF require nodules to fix nitrogen. These prokaryotes, some of which are endophytic, 
TABLE 1: Native host plants of Gluconacetobacter diazotrophicus and the tissues from which they were discovered.

\begin{tabular}{|c|c|c|c|}
\hline Crop & Latin name & Tissue & Source \\
\hline Sugarcane & Saccharum spp. & Root, stem, leaf, root hair & {$[18,28,101]$} \\
\hline Cameroon grass & Pennisetum purpureum & Root, stem & [102] \\
\hline Sweet potato & Ipomoea batatas & Root, stem & {$[63]$} \\
\hline Coffee & Coffea arabica & Root, stem, rhizosphere & {$[62]$} \\
\hline Finger millet (Ragi) & Eleusine coracana & Root, stem, leaf & {$[103]$} \\
\hline Tea & Camellia sinensis & Root & {$[104]$} \\
\hline Pineapple & Ananas comosus & Root, stem, leaf & [29] \\
\hline Wetland rice & Oryza sativa & Root, stem, rhizosphere & {$[31]$} \\
\hline Banana & Musa acuminata $\times$ balbisiana & Rhizosphere & {$[104]$} \\
\hline Carrot & Daucus carota & Root & [99] \\
\hline Radish & Raphanus sativus & Root & [99] \\
\hline Beetroot & Beta vulgaris & Root & [99] \\
\hline
\end{tabular}

contain in many cases fewer requirements to establish a symbiotic relationship with a host plant. Gluconacetobacter diazotrophicus is a bacterium originally found in sugarcane plant. This bacterium can actively fix atmospheric nitrogen and provide significant amounts of nitrogen to sugarcane plants. Besides nitrogen fixation, this bacterium possesses several attractive features, including being of monocot origin, being less plant species specific, and having no nodulestructure requirement for living and nitrogen fixation. For the past years, many studies were conducted to reveal different aspects of this bacterium, aiming to explore this bacterium for nitrogen fixation in other crops, especially monocot plants. This paper will review and discuss the research progress of $G$. diazotrophicus.

\section{Discovery, Classification, and Culture Media Requirements}

Some basic features of $G$. diazotrophicus and related research were described in a minireview by Muthukumarasamy et al. 10 years ago [17]. This paper will provide a comprehensive review and discuss the new progress on G. diazotrophicus research.

Gluconacetobacter diazotrophicus was discovered within sugarcane plants in Alagoas, Brazil, by Cavalcante and Dobereiner [18]. Since then, G. diazotrophicus has been found in places such as Mexico and India and in crops ranging from coffee to pineapple (Table 1). The bacterium was initially named as Saccharobacter nitrocaptans and was later classified under acetic acid bacteria and named Acetobacter diazotrophicus, before being reclassified as Gluconacetobacter diazotrophicus based on $16 \mathrm{~S}$ ribosomal RNA analysis [1820]. This bacterium is accommodated with in the phylum Proteobacteria, the class Alphaproteobacteria, the order Rhodospirillales, the family Acetobacteraceae, and genus Gluconacetobacter [21]. Gluconacetobacter diazotrophicus is a Gram-negative, nonspore forming, nonnodule producing, endophytic nitrogen fixing bacterium. The bacterium is an obligate aerobe with cells measuring $0.7-0.9 \mu \mathrm{m}$ by $2 \mu \mathrm{m}$ and appears as single, paired, or chainlike structures when viewed under a microscope. The bacterium's cells have 1-3 lateral or peritrichous flagella used for motility. G. diazotrophicus is an acid-tolerant bacterium, being capable of growing at $\mathrm{pH}$ levels below 3.0; however its optimum $\mathrm{pH}$ for growth is 5.5 $[18,19]$.

Growth of G. diazotrophicus under laboratory conditions is primarily achieved through plating on LGIP medium due to the fact that it contains high sugar levels which are very similar to those found within sugarcane (quantities per litre: $\mathrm{K}_{2} \mathrm{HPO}_{4}, 0.2 \mathrm{~g} ; \mathrm{KH}_{2} \mathrm{PO}_{4}, 0.6 \mathrm{~g} ; \mathrm{MgSO}_{4} \cdot 7 \mathrm{H}_{2} \mathrm{O}, 0.2 \mathrm{~g}$; $\mathrm{CaCl}_{2} \cdot 2 \mathrm{H}_{2} \mathrm{O}, 0.02 \mathrm{~g} ; \mathrm{Na}_{2} \mathrm{MoO}_{4} \cdot 2 \mathrm{H}_{2} \mathrm{O}, 0.002 \mathrm{~g} ; \mathrm{FeCl}_{3} \cdot 6 \mathrm{H}_{2} \mathrm{O}$, $0.01 \mathrm{~g}$; bromothymol blue in $0.2 \mathrm{M} \mathrm{KOH}, 0.025 \mathrm{~g}$; sucrose, $100 \mathrm{~g}$; yeast extract, $0.025 \mathrm{~g}$; agar, $15 \mathrm{~g} ; 1 \%$ acetic acid, pH 5.5) [18]. Other media capable of sustaining G. diazotrophicus growth include but are not limited to DYGS, C2, ATGUS, modified potato, SYP, AcD, GYC, and EYC media [2229]. The biochemical characteristics of G. diazotrophicus are listed in Table 2. Faster and more robust growth can be achieved through the addition of a nitrogen source to the LGIP medium, such as $10 \mathrm{mM} \mathrm{NH}_{4}\left(\mathrm{SO}_{4}\right)_{2}$. When grown on LGIP plates $G$. diazotrophicus can be visualized as smooth colonies with regular edges. Colonies on LGIP medium initially appear semitransparent but become dark orange in colour due to their uptake of bromothymol blue from within the medium following complete incubation [18, 19, 30-32]. As found within the bacterium's natural host sugarcane, G. diazotrophicus requires a large amount of sucrose for adequate growth [33]. With regard to growth under laboratory conditions, the bacterium is capable of growth in sucrose levels up to $30 \%$, while optimum growth is achieved at sucrose levels of $10 \%$. In addition to sucrose, $G$. diazotrophicus is capable of abundant growth on other carbon substrates including D-galactose, D-arabinose, D-fructose, and D-mannose [18].

\section{Key Metabolic Enzymes of G. diazotrophicus}

While G. diazotrophicus contains hundreds of enzymes, few have been examined as in depth as its nitrogenase, levansucrase, and pyrroloquinoline quinone-linked glucose dehydrogenase. Specifically regarding nitrogen fixation, these 
TABLE 2: General characteristics of Gluconacetobacter diazotrophicus.

\begin{tabular}{|c|c|}
\hline Characteristics & G. diazotrophicus \\
\hline Gram reaction & - \\
\hline $\begin{array}{l}\text { Dark brown colonies on potato agar with } \\
10 \% \text { sugar }\end{array}$ & + \\
\hline $\begin{array}{l}\text { Dark orange colonies on LGIP medium } \\
\text { with } 10 \% \text { sugar }\end{array}$ & + \\
\hline Motility & + \\
\hline $\mathrm{N}_{2}$ fixation & + \\
\hline $\mathrm{NO}_{3}$-reduction & - \\
\hline $\mathrm{N}_{2}$ fixation with $\mathrm{NO}_{3}^{-}$ & + \\
\hline Catalase & + \\
\hline Oxidase & - \\
\hline \multicolumn{2}{|l|}{ Growth on carbon sources } \\
\hline Sucrose ${ }^{*}$ & + \\
\hline Glucose & + \\
\hline Sorbitol & + \\
\hline Galactose & + \\
\hline Xylose & + \\
\hline Ethanol & + \\
\hline Sodium acetate & + \\
\hline Glycerol & + \\
\hline Arabinose & + \\
\hline Raffinose & + \\
\hline meso-Erythritol & + \\
\hline Fructose & + \\
\hline Maltose & + \\
\hline Rhamnose & + \\
\hline Trehalose & + \\
\hline Cellobiose & + \\
\hline Melibiose & + \\
\hline \multicolumn{2}{|l|}{$\begin{array}{l}\text { Growth on L-amino acids in the presence } \\
\text { of sorbitol as carbon source }\end{array}$} \\
\hline L-cysteine & + \\
\hline L-glutamine & + \\
\hline L-proline & + \\
\hline L-tryptophan & + \\
\hline L-aspartic acid & + \\
\hline
\end{tabular}

+: positive; -: negative.

* Only some strains were positive.

$[18,19,30-32]$.

three enzymes are essential, as the removal or mutation of one of the three could result in either the loss of the mechanism of nitrogen fixation, the energy to power nitrogen fixation, or the environment to sustain nitrogen fixation.

3.1. Nitrogenase. The nitrogenase of $G$. diazotrophicus is a molybdenum-dependent system (Mo-nitrogenase) and is capable of providing its host with a substantial amount of fixed nitrogen [34]. ${ }^{15} \mathrm{~N}$-aided nitrogen balance studies have shown that certain genotypes of sugarcane are capable of having up to $200 \mathrm{~kg} \mathrm{~N}$ per hectare fixed for them by G. diazotrophicus, meeting approximately half of the crop's nitrogen needs without the application of additional fertilizers $[35,36]$. The Mo-nitrogenase is made up of two component proteins, the Fe protein containing the ATP-binding sites and the MoFe protein containing the substrate binding sites [37]. A feature which may make nitrogen-fixation in G. diazotrophicus unique is that early reports indicated that it does not contain a nitrate reductase protein [18]. Without a nitrate reductase protein in the bacterium, it was hypothesized that there would not be feedback inhibition of nitrogenase by nitrate assimilation [18, 38]. However, more recent studies have suggested that the bacterium is inhibited to some extent by nitrate $[39,40]$. Additionally, the nitrogenase of $G$. diazotrophicus is not completely inhibited by the addition of ammonium (Table 3). However, G. diazotrophicus growth under field conditions has been shown to be inhibited by high levels of nitrogen fertilization [41]. Therefore, the bacterium is capable of nitrogen fixation in crops that are supplemented with either nitrate-based fertilizers or with low amounts of ammonium-based fertilizers [34, 42].

3.2. Levansucrase. G. diazotrophicus is unable to transport or take up sucrose, as such it secretes an extracellular enzyme called levansucrase, a fructosyltransferase exoenzyme which hydrolyzes sucrose into fructooligosaccharides and levan $[43,44]$. This enzyme is critical for the survival of the bacterium and can constitute over $70 \%$ of all secreted proteins by specific strains of $G$. diazotrophicus [43]. In addition to sucrose hydrolysis, levansucrase is also involved in tolerance to desiccation and $\mathrm{NaCl}$ and in biofilm formation [45]. Biofilm formation begins with the gumD gene homologue, an essential step in the production of exopolysaccharides, which along with levan, a product from the hydrolysis of sucrose by levansucrase, leads to the formation of biofilm in G. diazotrophicus $[45,46]$. The removal of either of these two factors results in the bacterium being unable to form a biofilm. This leads to changes in colony morphology, tolerances, nitrogenase activity, and abilities to aggregate to abiotic and biotic surfaces, resulting in diminished colonization abilities [45-47].

3.3. Pyrroloquinoline Quinone-Linked Glucose Dehydrogenase. G. diazotrophicus also contains a pyrroloquinoline quinone-linked glucose dehydrogenase (PQQ-GDH), which oxidizes glucose into gluconic acid in the extracellular environment $[48,49]$. More importantly, the PQQ-GDH, which is primarily synthesized under nitrogen fixing conditions, produces a large amount of energy for the bacterium. The increase of energy combined with the timing of the protein's synthesis, under nitrogen fixing condition, shows its importance in providing the bacterium with additional energy during nitrogen fixation, as there is a high energy demand associated with the conversion of dinitrogen by the nitrogenase [49]. While the principal pathway of glucose metabolism in $G$. diazotrophicus occurs through periplasmic oxidation via the PQQ-GDH, an alternate pathway exists, under specific 
TABle 3: Nitrogenase activity of Gluconacetobacter diazotrophicus strains Pal5 and Mad3A measured by acetylene reduction assay.

\begin{tabular}{|c|c|c|c|}
\hline \multirow{2}{*}{ Nitrogen sources } & \multicolumn{3}{|c|}{ Nitrogenase activity $\left(\mathrm{nmol} \mathrm{C}_{2} \mathrm{H}_{4} \mathrm{~h}^{-1} \mathrm{mg}^{-1}\right.$ protein) } \\
\hline & Pal5 & $\operatorname{Mad} 3 \mathrm{~A}$ & Control \\
\hline Nitrogen free & $296 \pm 16$ & 0 & 0 \\
\hline $1 \mathrm{mM} \mathrm{NO}_{3}^{-}$ & $269 \pm 15$ & 0 & 0 \\
\hline $10 \mathrm{mM} \mathrm{NO}_{3}^{-}$ & $228 \pm 21$ & 0 & 0 \\
\hline $1 \mathrm{mM} \mathrm{NO}_{4}^{+}$ & $103 \pm 19$ & 0 & 0 \\
\hline $10 \mathrm{mM} \mathrm{NO}_{4}^{+}$ & 0 & 0 & 0 \\
\hline
\end{tabular}

${ }^{*}$ Results are \pm SD averages of 3 replicates for each treatment (Yoon and Tian, unpublished).

TABLE 4: Plant growth promoting properties of G. diazotrophicus.

\begin{tabular}{|c|c|c|c|}
\hline Plant growth promotion & Traits & Capabilities & Sources \\
\hline Biological nitrogen fixation & $\mathrm{NH}_{4}^{+}$ & $\begin{array}{l}400-417 \text { nmoles of } \mathrm{C}_{2} \mathrm{H}_{4} \mathrm{hr}^{-1} \mathrm{mg}^{-1} \text { cell } \\
\text { protein }\end{array}$ & {$[105] ;[106]$} \\
\hline \multirow{3}{*}{ Phytohormone secretion } & IAA & $4-7 \mu \mathrm{g} \mathrm{mL}^{-1}$ & {$[87,105]$} \\
\hline & \multirow{2}{*}{ Gibberellin } & $\mathrm{GA}_{1}-1.6 \mathrm{ng} \mathrm{mL}{ }^{-1}$ & \multirow{2}{*}[52]{} \\
\hline & & $\mathrm{GA}_{3}-11.9 \mathrm{ng} \mathrm{mL}^{-1}$ & \\
\hline \multirow{2}{*}{ Mineral nutrient solubilization } & Phosphorus & 25-31 mm solubilization zone & {$[99]$} \\
\hline & Zinc & 30-48 mm solubilization zone & {$[99,107]$} \\
\hline \multirow[b]{2}{*}{ Phytopathogen antagonism } & Lysozyme-like bacteriocin & Inhibition of $X$. albilineans & [60] \\
\hline & Inhibition zone of mycelial growth & $\begin{array}{c}\text { F. solani, F. solani phaseoli, } F . \\
\text { sambucinum, F. culmorum, } F . \\
\text { moniliforme, F. graminearum, } H \text {. } \\
\text { carbonum }\end{array}$ & {$[61]$} \\
\hline
\end{tabular}

All data are dependent on strain and carbon source.

environmental conditions, in an intracellular pathway via the nicotinamide adenine dinucleotide (NAD)-linked glucose dehydrogenase (GDH) [50].

\section{Mechanism Aiding Plant Growth Promotion}

As a plant-growth-promoting bacterium, G. diazotrophicus aids its host plant in several different ways aside from nitrogen fixation. While specifically under nitrogen limiting conditions $G$. diazotrophicus nitrogenase activity has been shown to make sugarcane plants grow better. G. diazotrophicus growth promotion also occurs in nif ${ }^{-}$mutant strains, supporting the fact of additional plant-growth promoting benefits (Table 4) [27, 51]. G. diazotrophicus has been found to provide its host plants with phytohormones. Indole-3-acetic acid (IAA) and gibberellins A1 and A3 have been found to be produced by $G$. diazotrophicus, both phytohormones are critical for normal plant growth and development [28, 52, 53]. $G$. diazotrophicus has also been found to have phosphorous and zinc solubilisation capabilities [22, 54-57]. Zinc and phosphorus, micro and macronutrients, respectively, are important to the growth, development, and yield of many plants. Saravanan and colleagues [57] with the aid of Fourier transform infrared spectroscopy analysis identified gluconic acid as one of the key agents involved in the solubilisation of zinc. Through transposon mutant library screening, the importance of gluconic acid and its pathway was reaffirmed for not only zinc solubilisation but phosphorus solubilisation as well [22]. More specifically, a 5-ketogluconic acid anion, a derivative of gluconic acid, appears to be the key factor associated with mineral solubilisation, as revealed through gas chromatography coupled mass spectrometry analysis [56]. Additionally, zinc solubilization appears to deform $G$. diazotrophicus cells, causing large (approximately 10 times larger than normal) pleomorphic cells and aggregate-like cells [57]. Similar cellular deformation and appearance of pleomorphic cells were also noticed when the cultures were subjected to high nitrogen (in $\mathrm{NH}_{4}$ form) in the medium [17]. G. diazotrophicus has also been found to elicit a plant defence responses against Xanthomonas albilineans, a sugarcane pathogen [58]. X. albilineans causes leaf scald disease in sugarcane through its production of a xanthan-like polysaccharide product which can cause mature sugarcane plants to wilt and die [59]. G. diazotrophicus impedes the production of the leaf scald causing xanthan-like polysaccharide through its production of a lysozyme-like bacteriocin which results in the lysis of bacterial cells, effectively inhibiting the growth of $X$. albilineans [60]. In addition to antibacterial properties, $G$. diazotrophicus is also capable of antifungal activity against several Fusarium spp. and Helminthosporium spp. [61].

\section{Natural Colonization of G. diazotrophicus}

5.1. Native Host Plants. Aside from sugarcane, G. diazotrophicus has been discovered within a wide array of other organisms outside of its initial discovery within Brazil including 
TABle 5: Nonnative host plants of Gluconacetobacter diazotrophicus and the methods used for inoculation.

\begin{tabular}{lccc}
\hline Crop & Latin name & Method & Source \\
Corn & Zea mays & Seed inoculation & Cocking et al. 2006 [24]; Eskin 2012 [73]; Riggs et al. 2001 [27] \\
& & Aseptic inoculation & Root dip inoculation \\
Tomato & Lycopersicon esculentum & Aseptic inoculation & Tian et al. 2009 [23] \\
Arabadopsis & Arabidopsis thaliana & Aseptic inoculation & Cocking et al. 2006 [24] \\
& & Soil drench inoculation & Cocking et al. 2006 [24] \\
Sorghum & Sorghum vulgare & Seed inoculation & Paula et al. 1991 [63] \\
& & Root dip inoculation & Luna et al. 2010 [65] \\
Wheat & Triticum aestivum & Aseptic inoculation & Yoon 2011 [unpublished] \\
Oilseed rape & Brassica napus & Aseptic inoculation & Cocking et al. 2006 [24]; Luna et al. 2010 [65]; Youssef et al. 2004 [32] \\
White clover & Brassica napus & Aseptic inoculation & Cocking et al. 2006 [24] \\
Common bean & Phaseolus vulgaris & Aseptic inoculation & Cocking et al. 2006 [24] \\
\hline
\end{tabular}

coffee, pineapple, wetland rice, and many other crops as listed in Table 1 . The majority of these hosts contain relatively higher levels of sucrose which appeared to be a prerequisite for colonization by this bacterium [27]. G. diazotrophicus, an obligate endophyte, is incapable of surviving in soil without a plant host for more than two days, with the exception of being capable of surviving within the spores of the vesiculararbuscular mycorrhizal fungus Glomus clarum and within the root hairs of a host plant's rhizosphere $[62,63]$.

5.2. Avenues of Entry into Host. The bacterium is able to gain entry into its host plant through the roots, stems, or leaves [64]. With regard to the roots, G. diazotrophicus enters through the root tips and cells of the root cap and meristem, at areas of lateral root emergence and through root hairs [6466]. Within the stems of host plants, specifically sugarcane, the bacterium is capable of entering at breaks caused by the separation of plantlets into individuals [64]. Lastly, within the leaves, the bacterium's most probable location of entry would be though damaged stomata [64]. An additional mode of entry used by $G$. diazotrophicus is achieved through an insect vector, the pink sugarcane mealybug (Saccharicoccus sacchari), a plant sap-sucking insect $[67,68]$. Once within the host plant, G. diazotrophicus was found to primarily inhabit intercellular apoplastic spaces, the xylem, and the xylem parenchyma $[33,64]$. However, recent findings, aided with $\beta$ glucuronidase (GUS)-labeled G. diazotrophicus, suggest that this bacterium is also capable of intracellular colonization within membrane-bound vesicles in its host plant [24]. Established G. diazotrophicus colonies are capable of growing up to $10^{8} \mathrm{CFU}$ per gram of tissue, as found within sugarcane [69]. The aforementioned modes of entry for G. diazotrophicus appear to be aided by hydrolytic enzymes [70]. Within both PAL5 and UAP5541 strains of G. diazotrophicus, production of endoglucanase, endopolymethylgalacturonase, and endoxygluconase was confirmed using only sucrose as their sole carbon source [70]. These enzymes have the potential to be responsible for both the bacterium's ability to enter its host plant and its mobility once inside [70].

\section{Experimental Inoculation on Nonnative Host Plants}

6.1. Nonnative Host Plants. Gluconacetobacter diazotrophicus has also been found to be capable of surviving after inoculation in a wide variety of crops, including corn, sorghum, wheat, and many others as listed in Table 5. The capability to introduce this bacterium into nonhost crops does not only provide an opportunity for further research within an aseptic environment in order to determine specifics regarding this bacterium, such as its localization within its host, points of entry, increased accuracy in hormone production, and most importantly an estimate of its nitrogen fixation, but it also provides the ability for the experimental introduction of this bacterium into novel hosts in which characteristics such as nitrogen fixation are very important. Several different inoculation methods have been used to successfully introduce $G$. diazotrophicus into crops.

6.2. Aseptic Inoculation Experiments. One of the most efficient methods of ensuring successful colonization of a bacterium into a host is under gnotobiotic/aseptic conditions. By doing so one would ensure that no competition or inhibition is occurring due to the presence of additional endophytic bacteria. Many studies used an aseptic environment for their host plants when inoculating them with $G$. diazotrophicus $[24,64-66,71]$. The majority of the host plants in the aforementioned studies were grown on varying types of modified MS medium within growth chambers to which the bacterial inoculum was added. The bacterial inoculum ranged in both amounts from $100 \mu \mathrm{L}$ to $1 \mathrm{~mL}$ and CFU's $\mathrm{mL}^{-1}$ from $10^{6}$ to $10^{9}[24,32,64,66,71]$. Seed inoculation, another method of introducing the bacterium into the host, was investigated by Luna and colleagues [65] and involved inoculating $100 \mathrm{~g}$ of seeds with $10 \mathrm{~mL}$ of a $10^{8} \mathrm{CFU} \mathrm{mL}^{-1}$ bacterial culture in a 
TABLE 6: List of DNA primer sets for PCR detection of Gluconacetobacter diazotrophicus.

\begin{tabular}{lccc}
\hline Target & Primer name & Sequence & Source \\
\hline \multirow{2}{*}{ 23S rRNA } & AD & TGCGGCAAAAGCCGGAT & Arencibia et al. 2006 (Arencibia et al. 2006a) [58] \\
& HerbaGd & TGCGGCAAAAGCCGGAT & Kirchhof et al. 1998 [108] \\
23S rRNA & AD & TGCGGCAAAAGCCGGAT & Sievers et al. 1998 [109] \\
& 1440 & GTTGGCTTAGAAGCAGCC & Franke-Whittle et al. 2005 [67] \\
$16 \mathrm{~S}$ rRNA & AC & CTGTTTCCCGCAAGGGAC & Tian et al. 2009 [23] \\
& DI & CTGTTTCCCGCAAGGGAC & TGAGTAACGCGTAGGGATCTG \\
& GDI39F & GGAAACAGCCATCTCTGACTG & TAGTGGCGGACGGGTGAGTAACG \\
\hline
\end{tabular}

phosphate saline buffer at a pH of 6.0 [65]. Trujillo-López and colleagues [71] examined the interaction between the common bean and $G$. diazotrophicus associated with UV light stimulation as an abiotic stimulus for the promotion of secondary metabolite accumulation. While they were successful in observing secondary metabolite accumulation in the UV light stimulated seedlings, they also found that the seedlings inoculated $4 \mathrm{~h}$ after UV irradiation had 5.65 times the number of bacteria compared to control seedlings [71].

6.3. Greenhouse Inoculation Experiments. Studies carried out under greenhouse conditions are exposed to more factors than those grown under aseptic conditions and as such, provide a better understanding to the plant-bacterium interaction under less favorable conditions compared to those studied under aseptic conditions. Several different inoculation methods have been used in $G$. diazotrophicus studies. Tian and colleagues [23] found success with the root dip method of inoculation with corn. Plants were grown in the greenhouse to the 2-3 leaf stage at which point $10-15 \%$ of the roots were trimmed and submerged into a bacterial inoculum at $10^{8} \mathrm{CFU} \mathrm{mL}^{-1}$ for $30 \mathrm{~min}$ [23]. Another method of inoculation, as described by James and colleagues [64], involved directly injecting $1 \mathrm{~mL}$ of the bacterial inoculum at approximately $10^{8} \mathrm{CFU} \mathrm{mL}^{-1}$ into the growing sugarcanes "leaf pocket" at the base of the stem [64]. Seed inoculation, as mentioned earlier under the aseptic studies [65], can also be used under greenhouse conditions. Riggs and colleagues [27] successfully inoculated corn seeds by coating them with in a $10^{8} \mathrm{CFU} \mathrm{mL}{ }^{-1}$ bacterial suspension in peat which was followed by planting within $48 \mathrm{hrs}$ of the coating inoculation. Paula and colleagues [63] demonstrated through soil drench inoculation an increase in bacterial numbers when sugarcane was inoculated with the spores of the vesicular-arbuscular mycorrhizal (VAM) fungus Glomus clarum containing $G$. diazotrophicus compared to the bacterium alone. An additional method of inoculation specifically directed towards endophytic bacteria is foliar spraying [72]. While the majority of these methods are successful at introducing the bacterium into the host under laboratory and greenhouse conditions, more research should be directed at field level application. Additionally, with regard to methods of inoculation, our lab found that the method used in inoculating a host plant appears to be more important in determining successful colonization than the plant genotype [73].

\section{Identification, Quantification, and Localization of G. diazotrophicus}

7.1. Identification and Quantification of G. diazotrophicus. Several methods exist to examine plants for the presence of $G$. diazotrophicus. One of the main methods of identification of G. diazotrophicus is through PCR. A list of primers used to target $G$. diazotrophicus is listed in Table 6. While a simple PCR is sufficient in identifying the bacterium at high colony numbers, a nested PCR in which a second round of PCR is used to amplify the product from the first round of PCR is instrumental in detecting the bacterium when found at very low colony numbers [23]. While PCR is capable of confirming the presence of the bacterium, it is not capable of determining the number of bacterium present within a sample. As such, the most probable number (MPN) method, using a McCrady table, has been used to quantify the amount of bacteria within a sample [63]. However, the MPN method is not considered to be very accurate and must be subjected to further testing to confirm isolates at a species level, most commonly accomplished via PCR. In order to combat the inaccuracies of the MPN method, species-specific polyclonal antibodies have been used with indirect enzyme-linked immunosorbent assay (ELISA) to quantify G. diazotrophicus. Da SilvaFroufe and colleagues [26] have shown that using the same $G$. diazotrophicus sample, quantification using the ELISA technique produced bacterial numbers many times greater than those calculated by the MPN method.

7.2. Localization of $G$. diazotrophicus. In addition to determining presence and number, researchers have used several different techniques in identifying the bacterium's localization within its host plants $[24,64-66]$. James and colleagues [64] used immunogold labelling in which polyclonal antibodies were raised in rabbits against $G$. diazotrophicus, silver enhancement was also performed through the use of goat anti-rabbit antibodies [64]. With the aid of optical and transmission electron microscopy (TEM), confirmation of $G$. 
diazotrophicus endophytic colonization was made [64]. In addition to immunogold labelling, other methods used for localization studies include $G$. diazotrophicus marked with $g u s A$ and $g f p$ reporter genes from strains containing pHRGFPGUS ( $g f p:: g u s A)$ and pHRGFPTC ( $g f p)$ plasmids, respectively [24, 41, 65, 66]. G. diazotrophicus UAP5541/pRGS561 constitutively expressing GUS and UAP5541/pRGS562 with a nif $\mathrm{H}:$ :gus A transcriptional fusion are two additional strains that have been used in several studies in which both intercellular and intracellular localization have been determined [24, $41,65,66]$. More recently, in a study by Rouws and colleagues [66], G. diazotrophicus strain Pal5 carrying gfp::gusA plasmid pHRGFPGUS and $g f p$ plasmid pHRGFPTC were proven to be valid tools in monitoring localization and colonization.

\section{Molecular Research in G. diazotrophicus}

The recent sequencing of the Pal5 genome has greatly expanded our knowledge of G. diazotrophicus and has opened many new doors in regard to future directions of research. The study by Bertalan and colleagues [74] was accomplished by RioGene in Brazil and funded by FAPRJ. The US DOE Joint Genome Institute has also sequenced the PAL5 genome; however, many differences exist between the two sequences [75]. G. diazotrophicus was only the 3rd diazotroph and the 9th endophyte to be sequenced [74]. The PAL5 genome yielded one circular chromosome (3,944,163 bp) with a G-C content of $66.19 \%$ and two plasmids pGD01 (38,818 bp) and pGD02 (16,610 bp). Overall the genome contains 3,864 putative coding sequences (CDS) [74].

One thousand and seventy-seven hypothetical proteins were found in the sequenced genome, 583 of which have already been identified and used to describe potential metabolic pathways within G. diazotrophicus [74, 76]. Proteome studies have observed different levels of expression and have identified the roles of specific proteins involved in in vitro cultures in the presence or absence of a sugarcane host and involved in the exponential and stationary phases of G. diazotrophicus, in the presence of high and low levels of nitrogen $[76,77]$.

Through thorough analysis of the genome it was found that $G$. diazotrophicus contains many genes homologous to those within other bacteria [74]. Some of these genes have been found to augment resistance to acetic acid, which undoubtedly play an important role in allowing the bacterium to grow and fix nitrogen at $\mathrm{pH}$ levels of $2.5[74,78-$ 80]. Genes relating to production of gluconic acid can be important as the chemical is only produced during nitrogen fixing process. Other homolog genes which code for polysaccharides, including capsular polysaccharides, exopolysaccharides, and lipopolysaccharides, have been found to be involved in interactions between rhizobia and their host plants involved in invasion, nodule development, and protection and suppression against plant responses and antimicrobial compounds. These homologs could aid in further understanding specific actions with $G$. diazotrophicus $[74,81]$. In order to accurately evaluate gene expression, reference genes are required as a comparison for normalization. Three genes have recently been suggested as suitable reference genes in $G$. diazotrophicus for real-time qPCR, rho, 23SrRNA, and rpoD, as their expression levels were shown to be very stable across different carbon sources [82]. The G. diazotrophicus genome has also uncovered genes which can code for several different signalling mechanisms, including those involved in the synthesis of second messenger cyclic di-GMP's, cytoplasmic, and membrane bound histidine kinase signalling proteins including response regulator genes containing several chemotaxis genes and 3 quorum sensing genes [74]. Quorum sensing refers to the ability of a bacterium to respond to autoinducers, hormone-like molecules which are capable of altering gene expression at a critical threshold population [83]. The quorum sensing genes in $G$. diazotrophicus, which consist of one luxI autoinducer synthase gene and two luxR-type transcriptional regulators genes, have been found to code for three $N$-acyl homoserine lactones (AHLs) $[74,84-86]$. Analysis of G. diazotrophicus AHLs identified 8 different signalling molecules: C6-homoserine lactone (HSL), C8-HSL, C10-HSL, C12-HSL, C14-HSL, 3-oxo-C10-HSL, 3-oxo-C12HSL, and 3-oxo-C14-HSL [85]. Quorum sensing has been shown to regulate and be involved in many important functions and traits, including nitrogen fixation within Rhizobium etli [84].

While many of the G. diazotrophicus plant growthpromoting traits have been investigated, their specific pathways have yet to be properly defined. Regarding IAA, studies have shown that, within G. diazotrophicus, an approximate 95\% dropoff of IAA production occurs in cytochrome c mutants, meaning that $G$. diazotrophicus contains at least two independent pathways for IAA production [87]. Genome sequence analysis has shown that G. diazotrophicus does not possess indole 3-pyruvate carboxylase; as such, IAA could also be synthesized by either the trypamide pathways or by the indole-3-acetonitrole pathway [74]. G. diazotrophicus also appears to be capable of producing acetoin, a PGP volatile, based on the discovery of the gene homologs of key enzymes found in the acetoin pathway [74]. Volatile synthesis by G. diazotrophicus has yet to be investigated but could have a large impact in its PGP abilities [88]. As with the discovery of the previously discussed IAA mutant and of the more recently published flagellar mutant, Tn5 transposon mutagenesis appears to be the next step for the functional characterization of genes discovered in the genome sequence $[87,89]$. New molecular methods, such as the Tn5 transposon mutagenesis and plasmid insertions, such as those discussed under localization experiments have led to the creation of several new strains of $G$. diazotrophicus which are listed in Table 7.

With the sequenced genome available to researchers, new strides have been made in understanding the many processes of G. diazotrophicus at a molecular level [90]. Focussing on nitrogen fixation, and more specifically on the bacterium's ability to protect its nitrogenase against inhibition due to oxygen, previous studies have suggested that nitrogenase activity is controlled by an on/off-switch mechanism for $\mathrm{O}_{2}$ protection or that the bacterium utilizes colony mucilage, more specifically its position within it, to achieve optimal flux 
TABLE 7: A subset of G. diazotrophicus mutant, plasmid, and wild-type strains.

\begin{tabular}{|c|c|c|}
\hline Strain & Function & Source \\
\hline Pal5 & WT & Cavalcante and Dobereiner 1988 [18] \\
\hline UAP5541 & WT & Caballero-Mellado and Martinez-Romero 1994 [110] \\
\hline MAd3A & $\begin{array}{c}\text { nifD::aph mutant of Pal5 } \\
\text { Nif- }\end{array}$ & Sevilla et al. 1997 [96] \\
\hline MAd10 & $c c m$ mutant (6\% IAA) & Lee et al. 2004 [99] \\
\hline UAP5541/pRGS561 & Constitutive GUS expression & Fuentes-Ramírez et al. 1999 [41] \\
\hline UAP5541/pRGS562 & $\begin{array}{c}\text { nif } \mathrm{H}:: g u s \mathrm{~A} \\
\text { Transcriptional fusion }\end{array}$ & Fuentes-Ramírez et al. 1999 [41] \\
\hline Pal5/pHRGFPGUS & $g f p:: g u s A$ & Rouws et al. $2010[66]$ \\
\hline Pal5/pHRGFPTC & $g f p$ & Rouws et al. 2010 [66] \\
\hline $\begin{array}{l}\text { GDP29H1, GDP9G4, GDP12F6 } \\
\text { and GDP23A12 }\end{array}$ & Unable to solubilize zinc and phosphorous & Intorne et al. 2009 [22] \\
\hline AD5 & $\begin{array}{c}l s d A:: n p t I I-b l e \text { cassette } \\
\text { (Levansucrase) LsdA-deffective }\end{array}$ & Hernandez et al. 1995 [43] \\
\hline L-3 & $l s d A$ mutant & Velázquez-Hernández et al. 2011 [45] \\
\hline
\end{tabular}

in $\mathrm{O}_{2}$ for aerobic respiration while not inhibiting nitrogenase activity [47, 91]. Recently, with the aid of the sequenced Pal5 genome, a putative FeSII coding gene was identified which opened the possibility of $G$. diazotrophicus using conformational protection mechanisms for nitrogenase against oxygen [92]. However, oxygen is not the only inhibitor of nitrogenase, reactive oxygen species (ROS), by-products of aerobic metabolism critical in the production of ATP for the high energy-demanding process of nitrogen fixation, have also proven to be inhibitors of nitrogenase [37, 93]. While ROS levels were expected to increase during nitrogen fixation and elevated aerobic respiration, they in fact decreased within G. diazotrophicus, as six ROS-detoxifying genes have been found to be upregulated within nitrogen fixing cells, a potentially adaptive mechanism by the bacterium for nitrogen fixation [94]. Asparagine, important to microbial growth promotion, is also a nitrogenase inhibitor and has been found in high amounts in many of $G$. diazotrophicus host plants $[80,94]$. Genome sequencing has shown that $G$. diazotrophicus does not contain an asparagine synthetase ortholog, indicating that it requires an indirect pathway for asparagine biosynthesis [74]. Alquéres and colleagues [94] suggest the existence of a tRNA-dependent pathway for asparagine biosynthesis in $G$. diazotrophicus which ensures low intracellular levels of the amino acid.

Regarding biological nitrogen fixation, the recent sequenced genome corroborates with previous findings which have characterized the major cluster and associated genes of nitrogenase [95, 96]. Bertalan et al. [74] have also discovered that nitrogenase is not regulated at the posttranslational level and that, while the main route for ammonia assimilation is believed to occur through the glutamine synthetase/glutamate synthase pathway, alternative routes which would incorporate ammonia into different compounds can also exist.

\section{Conclusions and Future Directions of Research}

Over the past quarter of a century, since the original discovery of the bacterium, a lot of research has been conducted on G. diazotrophicus; named by some as the primary reason for the success of Brazil's bioethanol program and as the potential key to attaining BNF within nonlegume crops [40,97]. While the majority of studies in the past have primarily focused on understanding the bacterium, its traits, and characteristics, recent studies have moved toward a more molecular focus. The recent discovery of the bacterium's genome will now only further efforts in the molecular field, potentially unlocking the door to successful BNF in nonlegume crops.

Past studies regarding BNF have only definitively shown evidence within sugarcane [35]. Studies in which the bacterium was found within additional natural host plants, such as coffee and pineapple, have not proven that BNF occurs within the plant; instead, they only demonstrate that the strain isolated from the plant is capable of nitrogen-fixation. Future studies should put more emphasis on determining G. diazotrophicus BNF capabilities within plants other than sugarcane. ${ }^{15} \mathrm{~N}$-aided experiments, as conducted by Boddey et al. [35], could determine the bacterium's capability in fixing nitrogen within hosts outside of sugarcane.

Studies should also continue to focus on the importance of quorum sensing. While it has been discovered that $G$. diazotrophicus contains 3 different AHLs, their exact roles have yet to be identified. Quorum sensing has been found to play pivotal roles in other bacteria; within Rhizobium etli, it has been found to control BNF [84]. Newly identified molecular methods used in studying $G$. diazotrophicus such as mutational studies via Tn 5 transposon mutagenesis could 
help identify which quorum sensing genes, if any, play any role in BNF [98]. Furthermore, overexpression of any quorum sensing genes found linked to BNF could result in BNF in hosts previously incapable of acquiring such a symbiosis.

Research into wide array of natural and nonnatural host plants of G. diazotrophicus has led to its discovery within radish roots in India and its capability to be successfully inoculated into plants such as Arabidopsis, a well-known and extensively studied model organism [24, 99]. While the Arabidopsis plant has provided many scientific breakthroughs, it is limited as a model organism when investigating monocotspecific processes. However, Brachypodium distachyon has recently emerged as a new model organism for monocots [100]. With future goals associated with $G$. diazotrophicus revolving around its potential to fix nitrogen in crops such as corn, wheat, and rice, its interactions within monocot plants must be thoroughly studied at molecular level and $B$. distachyon may provide such a system.

\section{Conflict of Interests}

The authors declare that there is no conflict of interests regarding the publication of this paper.

\section{Acknowledgments}

The authors would like to thank Dorothy Drew, Erin Johnson, and Hui Fang of Agriculture and Agri-Food Canada, for helping with literature searching, reference checking, and formatting.

\section{References}

[1] J. N. Galloway, J. D. Aber, J. W. Erisman et al., “The nitrogen cascade," BioScience, vol. 53, no. 4, pp. 341-356, 2003.

[2] M. B. Peoples, D. F. Herridge, and J. K. Ladha, "Biological nitrogen fixation: an efficient source of nitrogen for sustainable agricultural production?" Plant and Soil, vol. 174, no. 1-2, pp. 328, 1995.

[3] J. M. Williamson, "The role of information and prices in the nitrogen fertilizer management decision: new evidence from the agricultural resource management survey," Journal of Agricultural and Resource Economics, vol. 36, no. 3, pp. 552-572, 2011.

[4] S. Wang, F. Liu, C. Chen, and X. Xu, "Life cycle emissions of greenhouse gas for ammonia scrubbing technology," Korean Journal of Chemical Engineering, vol. 24, no. 3, pp. 495-498, 2007.

[5] F. Below and P. Brandau, How Much Nitrogen Does Corn Need?, Agronomy Field Day, University of Illinois Extension, University of Illinois at Urbana-Champaign, 2001.

[6] N. D. Paulson and B. A. Babcock, "Re-addressing the fertilizer problem," Journal of Agricultural and Resource Economics, vol. 35, no. 3, pp. 368-384, 2010.

[7] K. G. Cassman, A. Dobermann, and D. T. Walters, "Agroecosystems, nitrogen-use efficiency, and nitrogen management," Ambio, vol. 31, no. 2, pp. 132-140, 2002.

[8] G. P. Robertson and P. M. Vitousek, "Nitrogen in agriculture: balancing the cost of an essential resource," Annual Review of Environment and Resources, vol. 34, pp. 97-125, 2009.
[9] V. Smil, "Nitrogen in crop production: an account of global flows," Global Biogeochemical Cycles, vol. 13, no. 2, pp. 647-662, 1999.

[10] P. M. Vitousek, J. D. Aber, R. W. Howarth et al., "Human alteration of the global nitrogen cycle: sources and consequences," Ecological Applications, vol. 7, no. 3, pp. 737-750, 1997.

[11] P. J. Weyer, J. R. Cerhan, B. C. Kross et al., "Municipal drinking water nitrate level and cancer risk in older women: the Iowa women's health study," Epidemiology, vol. 12, no. 3, pp. 327-338, 2001.

[12] A. H. Wolfe and J. A. Patz, "Reactive nitrogen and human health: acute and long-term implications," Ambio, vol. 31, no. 2, pp. 120 $125,2002$.

[13] R. W. F. Hardy and R. C. Burns, "Biological nitrogen fixation," Annual Review of Biochemistry, vol. 37, article 331, 1968.

[14] J. K. Vessey, K. Pawlowski, and B. Bergman, "Root-based $\mathrm{N}_{2}$ fixing symbioses: legumes, actinorhizal plants, Parasponia sp. and cycads," Plant and Soil, vol. 274, no. 1-2, pp. 51-78, 2005.

[15] P. Mylona, K. Pawlowski, and T. Bisseling, "Symbiotic nitrogen fixation," Plant Cell, vol. 7, no. 7, pp. 869-885, 1995.

[16] N. Garg and G. Geetanjali, "Symbiotic nitrogen fixation in legume nodules: process and signaling. A review," Agronomy for Sustainable Development, vol. 27, no. 1, pp. 59-68, 2007.

[17] R. Muthukumarasamy, G. Revathi, S. Seshadri, and C. Lakshminarasimhan, "Gluconacetobacter diazotrophicus (syn. Acetobacter diazotrophicus), a promising diazotrophic endophyte in tropics," Current Science, vol. 83, no. 2, pp. 137-145, 2002.

[18] V. A. Cavalcante and J. Dobereiner, "A new acid-tolerant nitrogen-fixing bacterium associated with sugarcane," Plant and Soil, vol. 108, no. 1, pp. 23-31, 1988.

[19] M. Gillis, K. Kersters, B. Hoste et al., "Acetobacter diazotrophicus sp. nov., a nitrogen-fixing acetic acid bacterium associated with sugarcane," International Journal of Systematic Bacteriology, vol. 39, no. 3, pp. 361-364, 1989.

[20] Y. Yamada, K.-I. Hoshino, and T. Ishikawa, "The phylogeny of acetic acid bacteria based on the partial sequences of $16 \mathrm{~S}$ ribosomal RNA: the elevation of the subgenus gluconoacetobacter to the generic level," Bioscience, Biotechnology and Biochemistry, vol. 61, no. 8, pp. 1244-1251, 1997.

[21] K. Kersters, P. Lisdiyanti, K. Komagata, and J. Swings, “The family acetobacteraceae: the genera acetobacter, acidomonas, asaia, gluconacetobacter, gluconobacter, and kozakia," in The Prokaryotes, M. Dworkin, S. Falkow, E. Rosenberg, K. H. Schleifer, and E. Stackebrandt, Eds., pp. 163-200, Springer, New York, NY, USA, 2006.

[22] A. C. Intorne, M. V. V. De Oliveira, M. L. Lima, J. F. Da Silva, F. L. Olivares, and G. A. De Souza Filho, "Identification and characterization of Gluconacetobacter diazotrophicus mutants defective in the solubilization of phosphorus and zinc," Archives of Microbiology, vol. 191, no. 5, pp. 477-483, 2009.

[23] G. Tian, P. Pauls, Z. Dong, L. M. Reid, and L. Tian, "Colonization of the nitrogen-fixing bacterium Gluconacetobacter diazotrophicus in a large number of Canadian corn plants," Canadian Journal of Plant Science, vol. 89, no. 6, pp. 1009-1016, 2009.

[24] E. C. Cocking, P. J. Stone, and M. R. Davey, "Intracellular colonization of roots of Arabidopsis and crop plants by Gluconacetobacter diazotrophicus," In Vitro Cellular and Developmental Biology, vol. 42, no. 1, pp. 74-82, 2006.

[25] A. Trujillo-López, O. Camargo-Zendejas, R. Salgado-Garciglia et al., "Erratum: Association of Gluconacetobacter diazotrophicus with roots of common bean (Phaseolus vulgaris) seedlings 
is promoted in vitro by UV light," Canadian Journal of Botany, vol. 84 , no. 3 , article 514, 2006.

[26] L. G. da Silva-Froufe, R. M. Boddey, and V. M. Reis, "Quantification of natural populations of Gluconacetobacter diazotrophicus and Herbaspirillum spp. In sugar cane (Saccharum spp.) using different polyclonal antibodies," Brazilian Journal of Microbiology, vol. 40, no. 4, pp. 866-878, 2009.

[27] P. J. Riggs, M. K. Chelius, A. L. Iniguez, S. M. Kaeppler, and E. W. Triplett, "Enhanced maize productivity by inoculation with diazotrophic bacteria," Australian Journal of Plant Physiology, vol. 28, no. 9, pp. 829-836, 2001.

[28] L. E. Fuentes-Ramirez, T. Jimenez-Salgado, I. R. AbarcaOcampo, and J. Caballero-Mellado, "Acetobacter diazotrophicus, an indoleacetic acid producing bacterium isolated from sugarcane cultivars of México," Plant and Soil, vol. 154, no. 2, pp. 145-150, 1993.

[29] A. Tapia-Hernández, M. R. Bustillos-Cristales, T. JiménezSalgado, J. Caballero-Mellado, and L. E. Fuentes-Ramírez, "Natural endophytic occurrence of Acetobacter diazotrophicus in pineapple plants," Microbial Ecology, vol. 39, no. 1, pp. 49-55, 2000.

[30] L. E. Fuentes-Ramírez, R. Bustillos-Cristales, A. TapiaHernández et al., "Novel nitrogen-fixing acetic acid bacteria, Gluconacetobacter johannae sp. nov. and Gluconacetobacter azotocaptans sp. nov., associated with coffee plants," International Journal of Systematic and Evolutionary Microbiology, vol. 51, no. 4, pp. 1305-1314, 2001.

[31] R. Muthukumarasamy, I. Cleenwerck, G. Revathi et al., "Natural association of Gluconacetobacter diazotrophicus and diazotrophic Acetobacter peroxydans with wetland rice," Systematic and Applied Microbiology, vol. 28, no. 3, pp. 277-286, 2005.

[32] H. H. Youssef, M. Fayez, M. Monib, and N. Hegazi, "Gluconacetobacter diazotrophicus: a natural endophytic diazotroph of Nile Delta sugarcane capable of establishing an endophytic association with wheat," Biology and Fertility of Soils, vol. 39, no. 6, pp. 391-397, 2004.

[33] D. Z. Dong Zhongmin, M. J. Canny, M. E. McCully et al., "A nitrogen-fixing endophyte of sugarcane stems. A new role for the apoplast," Plant Physiology, vol. 105, no. 4, pp. 1139-1147, 1994.

[34] K. Fisher and W. E. Newton, "Nitrogenase proteins from Gluconacetobacter diazotrophicus, a sugarcane-colonizing bacterium," Biochimica et Biophysica Acta, vol. 1750, no. 2, pp. 154$165,2005$.

[35] R. M. Boddey, J. C. Polidoro, A. S. Resende, B. J. R. Alves, and S. Urquiaga, "Use of the $15 \mathrm{~N}$ natural abundance technique for the quantification of the contribution of $\mathrm{N}_{2}$ fixation to sugar cane and other grasses," Australian Journal of Plant Physiology, vol. 28, no. 9, pp. 889-895, 2001.

[36] E. Lima, R. M. Boddey, and J. Döbereiner, "Quantification of biological nitrogen fixation associated with sugar cane using a $15 \mathrm{~N}$ aided nitrogen balance," Soil Biology and Biochemistry, vol. 19, no. 2, pp. 165-170, 1987.

[37] D. C. Rees and J. B. Howard, "Nitrogenase: standing at the crossroads," Current Opinion in Chemical Biology, vol. 4, no. 5, pp. 559-566, 2000.

[38] J. C. Trinchant and J. Rigaud, "Nitrite and nitric oxide as inhibitors of nitrogenase from soybean bacteroids," Applied and Environmental Microbiology, vol. 44, no. 6, pp. 1385-1388, 1982.

[39] J. K. Vessey and B. Pan, "Living a grounded life: growth and nitrogenase activity of Gluconacetobacter diazotrophicus on solid media in response to culture conditions," Symbiosis, vol. 35, no. 1-3, pp. 181-197, 2003.

[40] A. F. A. Medeiros, J. C. Polidoro, and V. M. Reis, "Nitrogen source effect on Gluconacetobacter diazotrophicus colonization of sugarcane (Saccharum spp.)," Plant and Soil, vol. 279, no. 1-2, pp. 141-152, 2006.

[41] L. E. Fuentes-Ramírez, J. Caballero-Mellado, J. Sepúlveda, and E. Martínez-Romero, "Colonization of sugarcane by Acetobacter diazotrophicus is inhibited by high N-fertilization," FEMS Microbiology Ecology, vol. 29, no. 2, pp. 117-128, 1999.

[42] M. P. Stephan, M. Oliveira, K. R. S. Teixeira, G. MartinezDrets, and J. Dobereiner, "Physiology and dinitrogen fixation of Acetobacter diazotrophicus," FEMS Microbiology Letters, vol. 77, no. 1, pp. 67-72, 1991.

[43] L. Hernandez, J. Arrieta, C. Menendez et al., "Isolation and enzymic properties of levansucrase secreted by Acetobacter diazotrophicus SRT4, a bacterium associated with sugar cane," Biochemical Journal, vol. 309, no. 1, pp. 113-118, 1995.

[44] C. Martínez-Fleites, M. Ortíz-Lombardía, T. Pons et al., "Crystal structure of levansucrase from the Gram-negative bacterium Gluconacetobacter diazotrophicus," Biochemical Journal, vol. 390, no. 1, pp. 19-27, 2005.

[45] M. L. Velázquez-Hernández, V. M. Baizabal-Aguirre, F. CruzVázquez et al., "Gluconacetobacter diazotrophicus levansucrase is involved in tolerance to $\mathrm{NaCl}$, sucrose and desiccation, and in biofilm formation," Archives of Microbiology, vol. 193, no. 2, pp. 137-149, 2011.

[46] C. H. S. G. Meneses, L. F. M. Rouws, J. L. Simões-Araújo, M. S. Vidal, and J. I. Baldani, "Exopolysaccharide production is required for biofilm formation and plant colonization by the nitrogen-fixing endophyte Gluconacetobacter diazotrophicus," Molecular Plant-Microbe Interactions, vol. 24, no. 12, pp. 14481458, 2011.

[47] Z. Dong, C. D. Zelmer, M. J. Canny et al., "Evidence for protection of nitrogenase from $\mathrm{O}_{2}$ by colony structure in the aerobic diazotroph Gluconacetobacter diazotrophicus," Microbiology, vol. 148, no. 8, pp. 2293-2298, 2002.

[48] M. M. Attwood, J. P. Van Dijken, and J. T. Pronk, "Glucose metabolism and gluconic acid production by Acetobacter diazotrophicus," Journal of Fermentation and Bioengineering, vol. 72, no. 2, pp. 101-105, 1991.

[49] M. L. Galar and J. L. Boiardi, "Evidence for a membrane bound pyrroloquinoline quinine-linked glucose dehydrogenase in Acetobacter diazotrophicus," Applied Microbiology and Biotechnology, vol. 43, no. 4, pp. 713-716, 1995.

[50] M. F. Luna, C. E. Bernardelli, M. L. Galar, and J. L. Boiardi, "Glucose metabolism in batch and continuous cultures of Gluconacetobacter diazotrophicus PAL 3," Current Microbiology, vol. 52, no. 3, pp. 163-168, 2006.

[51] M. Sevilla, R. H. Burris, N. Gunapala, and C. Kennedy, "Comparison of benefit to sugarcane plant growth and $15 \mathrm{~N}_{2}$ incorporation following inoculation of sterile plants with acetobacter diazotrophicus wild-type and Nif- mutant strains," Molecular Plant-Microbe Interactions, vol. 14, no. 3, pp. 358-366, 2001.

[52] F. Bastián, A. Cohen, P. Piccoli, V. Luna, R. Baraldi, and R. Bottini, "Production of indole-3-acetic acid and gibberellins $\mathrm{A} 1$ and $\mathrm{A} 3$ by Acetobacter diazotrophicus and Herbaspirillum seropedicae in chemically-defined culture media," Plant Growth Regulation, vol. 24, no. 1, pp. 7-11, 1998.

[53] V. S. Saravanan, M. Madhaiyan, J. Osborne, M. Thangaraju, and T. M. Sa, "Ecological occurrence of Gluconacetobacter 
diazotrophicus and nitrogen-fixing Acetobacteraceae members: their possible role in plant growth promotion," Microbial Ecology, vol. 55, no. 1, pp. 130-140, 2008.

[54] J. M. Crespo, J. L. Boiardi, and M. F. Luna, "Mineral phosphate solubilization activity of Gluconacetobacter diazotrophicus under P-limitation and plant root environment," Agricultural Sciences, vol. 2, pp. 16-22, 2011.

[55] C. Sarathambal, M. Thangaraju, C. Paulraj, and M. Gomathy, "Assessing the Zinc solubilization ability of Gluconacetobacter diazotrophicus in maize rhizosphere using labelled ${ }^{65} \mathrm{Zn}$ compounds," Indian Journal of Microbiology, vol. 50, pp. S103-S109, 2010.

[56] V. S. Saravanan, P. Kalaiarasan, M. Madhaiyan, and M. Thangaraju, "Solubilization of insoluble zinc compounds by Gluconacetobacter diazotrophicus and the detrimental action of zinc ion $\left(\mathrm{Zn}^{2+}\right)$ and zinc chelates on root knot nematode Meloidogyne incognita," Letters in Applied Microbiology, vol. 44, no. 3, pp. 235-241, 2007.

[57] V. S. Saravanan, J. Osborne, M. Madhaiyan et al., "Zinc metal solutilization by Gluconacetobacter diazotrophicus and induction of pleomorphic cells," Journal of Microbiology and Biotechnology, vol. 17, no. 9, pp. 1477-1482, 2007.

[58] A. D. Arencibia, Y. Estevez, F. Vinagre et al., "Induced-resistance in sugarcane against pathogenic bacteria Xanthomonas albilineans mediated by an endophytic interaction," Sugar Tech, vol. 8, no. 4, pp. 272-280, 2006.

[59] B. Fontaniella, C. W. Rodríguez, D. Piñón, C. Vicente, and M.E. Legaz, "Identification of xanthans isolated from sugarcane juices obtained from scalded plants infected by Xanthomonas albilineans," Journal of Chromatography B, vol. 770, no. 1-2, pp. 275-281, 2002.

[60] Y. Blanco, M. Blanch, D. Piñón, M.-E. Legaz, and C. Vicente, "Antagonism of Gluconacetobacter diazotrophicus (a sugarcane endosymbiont) against xanthomonas albilineans (pathogen) studied in alginate-immobilized sugarcane stalk tissues," Journal of Bioscience and Bioengineering, vol. 99, no. 4, pp. 366-371, 2005.

[61] S. Mehnaz and G. Lazarovits, "Inoculation effects of Pseudomonas putida, Gluconacetobacter azotocaptans, and Azospirillum lipoferum on corn plant growth under greenhouse conditions," Microbial Ecology, vol. 51, no. 3, pp. 326-335, 2006.

[62] T. Jimenez-Salgado, L. E. Fuentes-Ramirez, A. TapiaHernandez, M. A. Mascarua-Esparza, E. Martinez-Romero, and J. Caballero-Mellado, "Coffea arabica L., a new host plant for Acetobacter diazotrophicus, and isolation of other nitrogenfixing acetobacteria," Applied and Environmental Microbiology, vol. 63, no. 9, pp. 3676-3683, 1997.

[63] M. A. Paula, V. M. Reis, and J. Döbereiner, "Interactions of Glomus clarum with Acetobacter diazotrophicus in infection of sweet potato (Ipomoea batatas), sugarcane (Saccharum spp.), and sweet sorghum (Sorghum vulgare)," Biology and Fertility of Soils, vol. 11, no. 2, pp. 111-115, 1991.

[64] E. K. James, F. L. Olivares, A. L. M. De Oliveira, F. B. Dos Reis Jr., L. G. Da Silva, and V. M. Reis, "Further observations on the interaction between sugar cane and Gluconacetobacter diazotrophicus under laboratory and greenhouse conditions," Journal of Experimental Botany, vol. 52, no. 357, pp. 747-760, 2001.

[65] M. F. Luna, M. L. Galar, J. Aprea, M. L. Molinari, and J. L. Boiardi, "Colonization of sorghum and wheat by seed inoculation with Gluconacetobacter diazotrophicus," Biotechnology Letters, vol. 32, no. 8, pp. 1071-1076, 2010.
[66] L. F. M. Rouws, C. H. S. G. Meneses, H. V. Guedes, M. S. Vidal, J. I. Baldani, and S. Schwab, "Monitoring the colonization of sugarcane and rice plants by the endophytic diazotrophic bacterium Gluconacetobacter diazotrophicus marked with gfp and gusA reporter genes," Letters in Applied Microbiology, vol. 51, no. 3, pp. 325-330, 2010.

[67] I. H. Franke-Whittle, M. G. O’Shea, G. J. Leonard, and L. I. Sly, "Design, development, and use of molecular primers and probes for the detection of Gluconacetobacter species in the pink sugarcane mealybug," Microbial Ecology, vol. 50, no. 1, pp. 128-139, 2005.

[68] P. Ortega-Rodés, E. Ortega, D. Kleiner, F. G. Loiret, R. Rodés, and J. Caballero-Mellado, "Low recovery frequency of Gluconacetobacter diazotrophicus from plants and associated mealybugs in Cuban sugarcane fields," Symbiosis, vol. 54, no. 3, pp. 131-138, 2011.

[69] V. M. Reis, F. L. Olivares, and J. Dobereiner, "Improved methodology for isolation of Acetobacter diazotrophicus and confirmation of its endophytic habitat," World Journal of Microbiology and Biotechnology, vol. 10, no. 4, pp. 401-405, 1994.

[70] M. Adriano-Anaya, M. Salvador-Figueroa, J. A. Ocampo, and I. García-Romera, "Plant cell-wall degrading hydrolytic enzymes of Gluconacetobacter diazotrophicus," Symbiosis, vol. 40, no. 3, pp. 151-156, 2005.

[71] A. Trujillo-López, O. Camargo-Zendejas, R. Salgado-Garciglia et al., "Erratum: Association of Gluconacetobacter diazotrophicus with roots of common bean (Phaseolus vulgaris) seedlings is promoted in vitro by UV light," Canadian Journal of Botany, vol. 84 , no. 3 , p. $514,2006$.

[72] W. Bressan and M. T. Borges, "Delivery methods for introducing endophytic bacteria into maize," BioControl, vol. 49, no. 3, pp. 315-322, 2004.

[73] N. Eskin, Colonization of Zea mays by the nitrogen fixing bacterium Gluconacetobacter diazotrophicus, biology [M.S. thesis], University of Western Ontario, London, Canada, 2012.

[74] M. Bertalan, R. Albano, V. de Pádua et al., "Complete genome sequence of the sugarcane nitrogen-fixing endophyte Gluconacetobacter diazotrophicus Pal5," BMC Genomics, vol. 10, article 1471, p. 450, 2009.

[75] A. Giongo, H. L. Tyler, U. N. Zipperer, and E. W. Triplett, “Two genome sequences of the same bacterial strain, Gluconacetobacter diazotrophicus PAl 5, suggest a new standard in genome sequence submission," Standards in Genomic Sciences, vol. 2, no. 3, pp. 309-317, 2010.

[76] L. M. S. Lery, A. Coelho, W. M. A. Von Kruger et al., "Protein expression profile of Gluconacetobacter diazotrophicus PAL5, a sugarcane endophytic plant growth-promoting bacterium (Proteomics 8, 8, (1631-1644) DOI: 10.1002/pmic.200700912)," Proteomics, vol. 8, no. 22, p. 4833, 2008.

[77] M. F. dos Santos, V. L. Muniz de Pádua, E. de Matos Nogueira, A. S. Hemerly, and G. B. Domont, "Proteome of Gluconacetobacter diazotrophicus co-cultivated with sugarcane plantlets," Journal of Proteomics, vol. 73, no. 5, pp. 917-931, 2010.

[78] S. Nakano, M. Fukaya, and S. Horinouchi, "Putative ABC transporter responsible for acetic acid resistance in Acetobacter aceti," Applied and Environmental Microbiology, vol. 72, no. 1, pp. 497-505, 2006.

[79] O.-K. Akiko, Y. Wang, K. Sachiko, T. Kenji, K. Yukimichi, and Y. Fujiharu, "Cloning and characterization of groESL operon in Acetobacter aceti," Journal of Bioscience and Bioengineering, vol. 94, no. 2, pp. 140-147, 2002. 
[80] N. A. Tejera, E. Ortega, R. Rodés, and C. Lluch, "Influence of carbon and nitrogen sources on growth, nitrogenase activity, and carbon metabolism of Gluconacetobacter diazotrophicus," Canadian Journal of Microbiology, vol. 50, no. 9, pp. 745-750, 2004.

[81] A. Skorupska, M. Janczarek, M. Marczak, A. Mazur, and J. Król, "Rhizobial exopolysaccharides: genetic control and symbiotic functions," Microbial Cell Factories, vol. 5, article no. 7, 2006.

[82] P. S. Galisa, H. A. P. da Silva, A. V. M. Macedo et al., "Identification and validation of reference genes to study the gene expression in Gluconacetobacter diazotrophicus grown in different carbon sources using RT-qPCR," Journal of Microbiological Methods, vol. 91, pp. 1-7, 2012.

[83] N. C. Reading and V. Sperandio, "Quorum sensing: the many languages of bacteria," FEMS Microbiology Letters, vol. 254, no. 1, pp. 1-11, 2006.

[84] R. Daniels, D. E. De Vos, J. Desair et al., "The cin quorum sensing locus of Rhizobium etli CNPAF512 affects growth and symbiotic nitrogen fixation," The Journal of Biological Chemistry, vol. 277, no. 1, pp. 462-468, 2002.

[85] C. G. Nieto-Peñalver, E. V. Bertini, and L. I. C. de Figueroa, "Identification of N-acyl homoserine lactones produced by Gluconacetobacter diazotrophicus PAL5 cultured in complex and synthetic media," Archives of Microbiology, vol. 194, pp. 615$622,2012$.

[86] P. Williams, K. Winzer, W. C. Chan, and M. Cámara, "Look who's talking: communication and quorum sensing in the bacterial world," Philosophical Transactions of the Royal Society $B$, vol. 362, no. 1483, pp. 1119-1134, 2007.

[87] S. Lee, M. Flores-Encarnación, M. Contreras-Zentella, L. Garcia-Flores, J. E. Escamilla, and C. Kennedy, "Indole-3-acetic acid biosynthesis is deficient in Gluconacetobacter diazotrophicus strains with mutations in cytochrome c biogenesis genes," Journal of Bacteriology, vol. 186, no. 16, pp. 5384-5391, 2004.

[88] C.-M. Ryu, M. A. Farag, C.-H. Hu, M. S. Reddy, J. W. Kloepper, and P. W. Paré, "Bacterial volatiles induce systemic resistance in Arabidopsis," Plant Physiology, vol. 134, no. 3, pp. 1017-1026, 2004.

[89] L. F. M. Rouws, J. L. Simões-Araújo, A. S. Hemerly, and J. I. Baldani, "Validation of a Tn5 transposon mutagenesis system for Gluconacetobacter diazotrophicus through characterization of a flagellar mutant," Archives of Microbiology, vol. 189, no. 4, p. 427, 2008.

[90] L. S. Urzúa, A. P. Vázquez-Candanedo, A. Sánchez-Espíndola, C. Á. Ramírez, and B. E. Baca, "Identification and characterization of an iron ABC transporter operon in Gluconacetobacter diazotrophicus Pal 5," Archives of Microbiology, vol. 195, no. 6, pp. 431-438, 2013.

[91] B. O. Pan and J. K. Vessey, "Response of the Endophytic Diazotroph Gluconacetobacter diazotrophicus on Solid Media to Changes in Atmospheric Partial O2 Pressure," Applied and Environmental Microbiology, vol. 67, no. 10, pp. 4694-4700, 2001.

[92] L. M. S. Lery, M. Bitar, M. G. S. Costa, S. C. S. Rössle, and P. M. Bisch, "Unraveling the molecular mechanisms of nitrogenase conformational protection against oxygen in diazotrophic bacteria," BMC Genomics, vol. 11, supplement 5, article S7, 2010.

[93] R. L. Robson and J. R. Postgate, "Oxygen and hydrogen in biological nitrogen fixation," Annual Review of Microbiology, vol. 34, pp. 183-207, 1980.
[94] S. M. C. Alquéres, J. H. M. Oliveira, E. M. Nogueira et al., "Antioxidant pathways are up-regulated during biological nitrogen fixation to prevent ROS-induced nitrogenase inhibition in Gluconacetobacter diazotrophicus," Archives of Microbiology, vol. 192, no. 10, pp. 835-841, 2010.

[95] S. Lee, A. Reth, D. Meletzus, M. Sevilla, and C. Kennedy, "Characterization of a major cluster of nif, fix, and associated genes in a sugarcane endophyte, Acetobacter diazotrophicus," Journal of Bacteriology, vol. 182, no. 24, pp. 7088-7091, 2000.

[96] M. Sevilla, D. Meletzus, K. Teixeira et al., "Analysis of nif and regulatory genes in acetobacter diazotrophicus," Soil Biology and Biochemistry, vol. 29, no. 5-6, pp. 871-874, 1997.

[97] E. W. Triplett, "Diazotrophic endophytes: progress and prospects for nitrogen fixation in monocots," Plant and Soil, vol. 186, no. 1, pp. 29-38, 1996.

[98] L. F. M. Rouws, J. L. Simões-Araújo, A. S. Hemerly, and J. I. Baldani, "Validation of a Tn5 transposon mutagenesis system for Gluconacetobacter diazotrophicus through characterization of a flagellar mutant," Archives of Microbiology, vol. 189, no. 4, pp. 397-405, 2008.

[99] M. Madhaiyan, V. S. Saravanan, D. B. S. S. Jovi et al., "Occurrence of Gluconacetobacter diazotrophicus in tropical and subtropical plants of Western Ghats, India," Microbiological Research, vol. 159, no. 3, pp. 233-243, 2004.

[100] J. Brkljacic, E. Grotewold, R. Scholl et al., "Brachypodium as a model for the grasses: today and the future," Plant Physiology, vol. 157, no. 1, pp. 3-13, 2011.

[101] R. P. Li and I. C. Macrae, "Specific association of diazotrophic acetobacters with sugarcane," Soil Biology and Biochemistry, vol. 23, no. 10, pp. 999-1002, 1991.

[102] J. Dobereiner and V. M. Reis, "Endophytic diazotrophs in sugar cane, cereals and tuber plants," in New Horizons in Nitrogen Fixation, R. Palacios, J. Mora, and W. E. Newton, Eds., pp. 671676, Springer Netherlands, 1993.

[103] P. Loganathan, R. Sunita, A. K. Parida, and S. Nair, "Isolation and characterization of two genetically distant groups of Acetobacter diazotrophicus from a new host plant Eleusine coracana L," Journal of Applied Microbiology, vol. 87, no. 1, pp. 167-172, 1999.

[104] V. Matiru and J. Thomson, "Can Acetobacter diazotrophicus be used as a growth promoter for coffee, tea, and banana plants?" in Proceedings of the 8th Congress of the African Association of Biological Nitrogen Fixation, F. D. Dakora, Ed., pp. 129-130, University of Cape Town, 1998.

[105] K. G. Anitha and M. Thangaraju, "Growth promotion of rice seedling by Gluconacetobacter diazotrophicus under in vivo conditions," Journal of Cell \& Plant Sciences, vol. 1, pp. 6-12, 2010.

[106] M. Meenakshisundaram and K. Santhaguru, "Isolation and nitrogen fixing efficiency of a novel endophytic diazotroph Gluconacetobacter diazotrophicus associated with Saccharum officinarum from southern district of tamilnadu," International Journal of Biological \& Medical Research, vol. 1, pp. 298-300, 2010.

[107] V. S. Saravanan, M. Madhaiyan, and M. Thangaraju, "Solubilization of zinc compounds by the diazotrophic, plant growth promoting bacterium Gluconacetobacter diazotrophicus," Chemosphere, vol. 66, no. 9, pp. 1794-1798, 2007.

[108] G. Kirchhof, J. Baldani, V. M. Reis, and A. I. Hartmannet, "Molecular assay to identify Acetobacter diazotrophicus and detect its occurrence in plant tissue," Canadian Journal of Microbiology, vol. 44, pp. 12-19, 1998. 
[109] M. Sievers, H. G. Schlegel, J. Caballero-Mellado, J. Dobereiner, and W. Ludwig, "Phylogenetic identification of two major, nitrogen-fixing bacteria associated with sugarcane," Systematic and Applied Microbiology, vol. 21, pp. 505-508, 1998.

[110] J. Caballero-Mellado and E. Martinez-Romero, "Limited genetic di-versity in the endophytic sugarcane bacterium Acetobacter diazotrophicus," Applied Environmental Microbiology, vol. 60, pp. 1532-1537, 1994. 


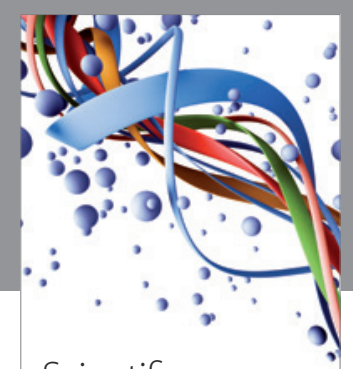

Scientifica
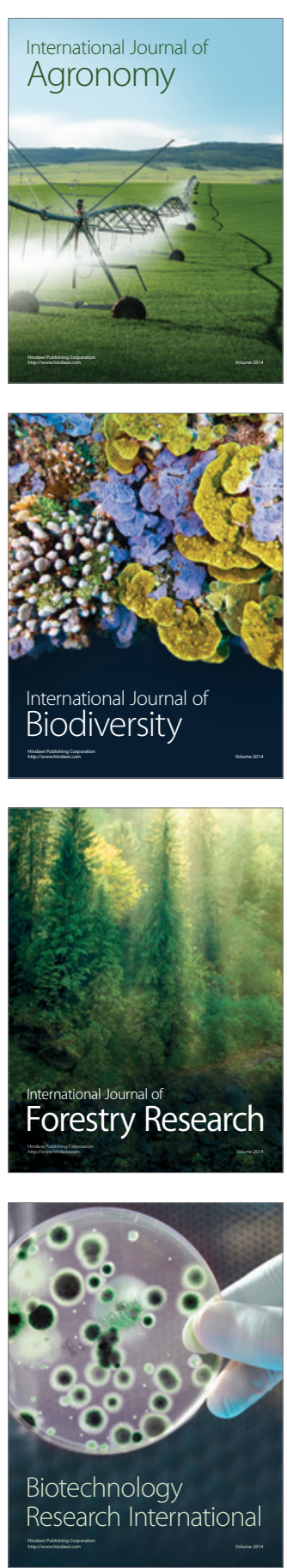
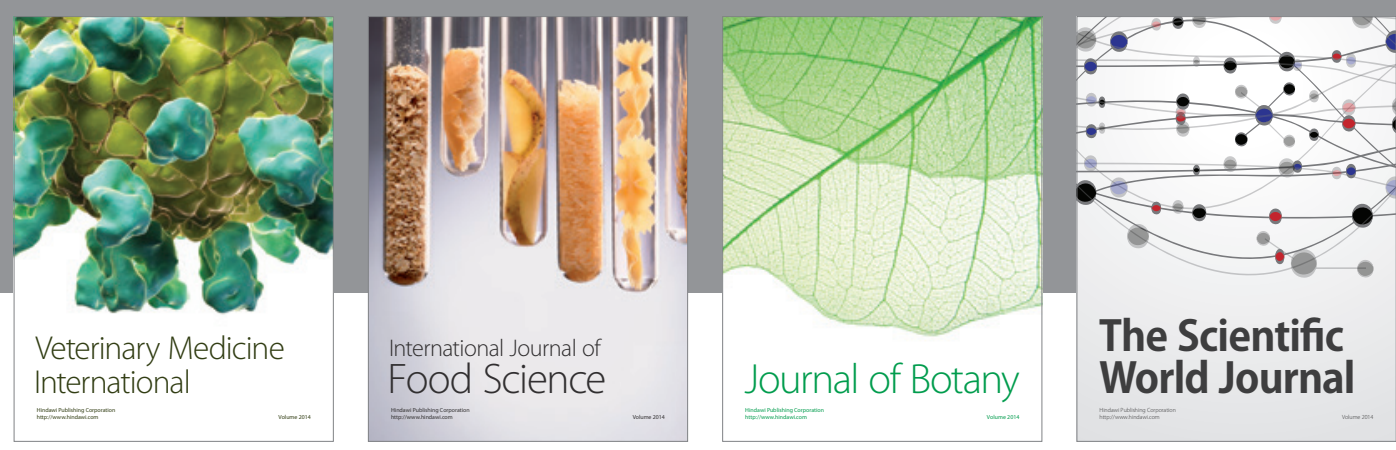

The Scientific World Journal
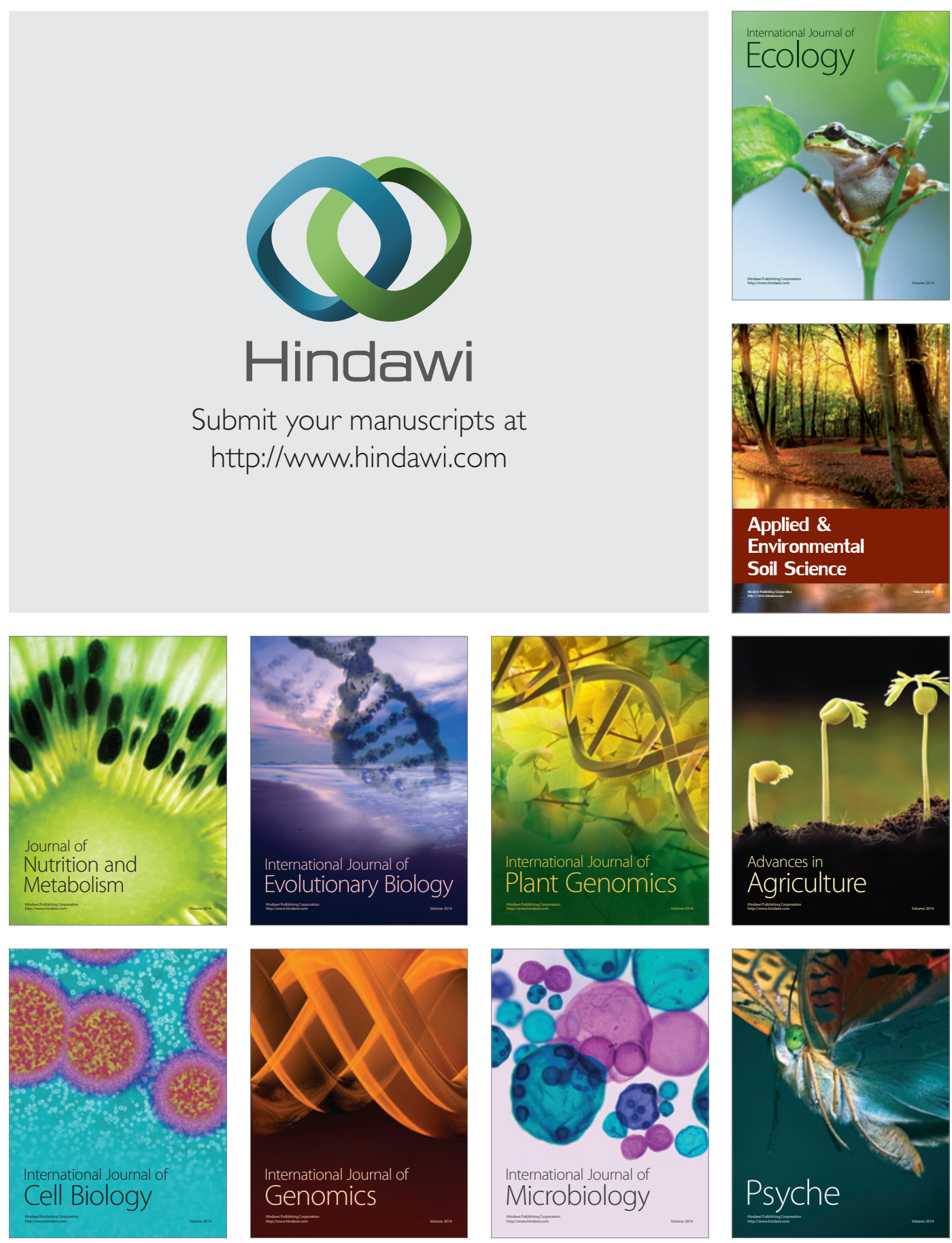